\title{
El trabajo del que está vivo es buscar al que está muerto
}

\section{Diego Romero ${ }^{1}$}

No tengo ninguna intención de relato, no alcanzo a apretar las experiencias de manera adecuada a la narración. Solo tengo certezas de ciertas preguntas, de ciertas respuestas que, en su momento, fueron la intriga de alguien en ese lugar de la insoluble pregunta. Las cosas en vano resultan bellas muchas veces. La literatura desparramada, confusamente disparada por el mar, una mesa en aquella escuela de barro, pescados y libros rellenando el camino de la carretilla.

Pensar en aquella ocupación en vez de los muertos y los estómagos, algo torcido hacia adentro que resultó otra vez por fuera. Con una carretilla y avanzando, con una pequeña ambición colmada de inocencia más que de certezas, así fue dicha labor.

Recuerdo un hombre con su hijo: - ¿Cómo se llama?-Mirador del sur. Es grande, parecido a ese de allá. -Yo vi muchos en la playa, adentro de esa casa blanca hay como tres. Mientras unos buscaban sus barcos, otros buscaban libros. Dichato se desplegaba por los hombres nuevamente.

No deja de ser inocente. En ese lugar donde aún se pensaba en otra ola, una fila de delgadez, lo que sostiene el pensamiento en aquellas fábricas, una frágil mesa hedionda, sirviendo para lo que fue hecha, sostener un libro.

-Llévenselo todo no ma', yo no quiero na de eso. -Uuh ya, pero mire este sí está nuevo, se puede hasta vender, le apuesto que alguien se los va a llevar.

En un momento gustó tanto el iluso rescate literario que resultamos ser cinco recolectores. La colección de Agatha Christie, García Márquez en su nave náutica impermeable, Neruda y De Roca pudriéndose juntos mirándose a través de un pescado. Todo lo posible fue cargado. No importó mucho cuando en la tarde se negó la utilidad de ganar algo con ellos, no dejó de funcionar la mínima conciencia de rescate y de manera intermitente, el gusto por llevarse uno. Quién pensaría que Plutarco logró salvarse del 
agua y ahora gozar de una cómoda jubilación en una colección de olores. Cuantas enciclopedias familiares soportaron la ola y todas esas tardes escolares.

Todos esos sentidos revueltos, cada uno un disparate, llenos del olor de su soporte natural, todos libros mojados. Era de esperar, había que quemarlo todo, Las infecciones y las máquinas tendrían que juntarlo todo y quemarlo.

Al menos esa era la noticia, y la mayoría dejaría el lugar, entrarían las maquinarias y los bomberos guardarían sus botas. El lugar no era apto para la salud de nadie, tal vez aparezca un muerto, una niña perdida, el hermano que bajó a buscar al hermano. Pero las infecciones impedían la labor. Para entonces no estaríamos, así que en esa tarde los libros se secaron con el sol y el fuego a distancia y, por sorpresa, codificados por la televisión para el filtro total de la sociedad. Un trabajo casi en vano, fuera del rescate de algunos hediondos rescates.

Pero en algún momento se dio a lo iluso de aquella ocupación un lugar en la existencia y nadie lo impidió; era algo improbable negarle a un libro su posibilidad de secarse y colmar de aire sus páginas. Trabajo imposible pero no inútil (replico ahora). La imagen, la inocente literatura del rescate junto a aquella montaña de basura estatal, barro blanco de aquella pequeña escuela. Insisto, dicha labor, tenía algo de sentido, en algún momento, no sé cuando, tal vez ahora no, pero en aquella mañana cuando dejé de lado las camionetas y tomé esa carretilla, algo de sentido encontré, y los curiosos hombres que levantaban uno y preguntaban si podían llevarse aquel, también. Al menos, algunos libros cargaron sus infecciones en secreto y ahora se ofenden de la hoguera.

\section{Nota}

1 Licenciado en Filosofía de la Universidad Católica de Valparaíso. 